\title{
RECENT WORK IN CONNECTIVISM
}

\author{
Stephen Downes[stephen@downes.ca],National Research Council Canada,1200 Montreal Road, Ottawa, \\ Canada
}

\begin{abstract}
Since the introduction of connectivism as a learning theory in 2004 a body of literature has developed both offering criticisms and expanding on applications and empirical validation. This article surveys recent literature on the topic, grouping it into themes, and developing an understanding of current perspectives in connectivism. It surveys current perspectives and criticisms of connectivism, views of connectivism as a pedagogy and as a theory of learning, recent evidence supporting connectivism, and a wider understanding of connectivism as it is developing today.
\end{abstract}

\section{Abstract in French}

Depuis l'introduction du connectivisme en tant que théorie de l'apprentissage en 2004, un corpus de littérature a été développé, offrant à la fois des critiques et une extension des applications et une validation empirique. Cet article examine la littérature récente sur le sujet, en le regroupant par thèmes et en développant une compréhension des perspectives actuelles en matière de connectivisme. Il passe en revue les perspectives actuelles et les critiques du connectivisme, les vues du connectivisme en tant que pédagogie et théorie de l'apprentissage, les preuves récentes soutenant le connectivisme et une compréhension plus large du connectivisme tel qu'il se développe aujourd'hui.

Keywords: connectivism, MOOC, pedagogy, learning theory, autonomy, interactivity

\section{Purpose and Method}

\section{Connectivism}

Connectivism was introduced as a coherent theory by Siemens in 2004. This initial formulation was followed though discussion and enhancements in a connectivism conference in 2007 and a series of massive online courses titled "Connectivism and Connective Knowledge" (2008, 2009, 2011, 2012). It can be characterized as a network theory of knowledge and learning with an emphasis on the use of digital technology to enhance and extend interaction online.

Probably the most comprehensive description of connectivism in recent years can be found in Al Dahdouh, Osórioand, and Caires (2015). They begin by considering connectivism as a theory of knowledge and outline it as follows:

"It does not make sense to consider learning merely as an internal construction of knowledge. Rather, what learners can reach in the external network should be considered as learning. Moreover, the knowledge itself has a structure; it is not something fuzay or mysterious. It is complex and chaotic, of course, but it has a structure."

Connectivism, though, is most often thought of as a theory of learning and pedagogy. Significantly, the study of connectivism resulted in the development of the first Massive Open Online Course (MOOC), "Connectivism and Connective Knowledge", offered through the 
University of Manitoba in 2008. Just as the study of MOOCs has continued in the years since, so has the study of connectivism.

This focus on recent interpretations of connectivism serves two objectives. First, it allows the reader to consider whether the theory has evolved or changed over the first decade and a half of its existence. And second, it allows the reader to consider what aspects of connectivism are seen to be especially relevant in the current environment.

\section{Method}

Material for this survey was gathered from the past year of academic literature referencing the term connectivism. Google Scholar was employed to conduct the search, from which papers were selected based whether or not they discussed connectivism, and whether they constituted part of the academic literature (that is, magazine articles and blog posts were not considered for this study). Specifically, the search term connectivism was used to discover the papers, and the search option "since 2018" selected. The author was signed in with a Google account during the search; signing in with a different account may change the order of the results. Many more results were available; the selection of papers was obtained from the first 12 pages of search results.

Only papers that were openly accessible to the public without payment were included in this survey. Papers that were not openly published, that is, only available behind a subscription paywall, cannot be viewed by the wider community. Their contents, and therefore the interpretation offered in this paper, cannot be verified by most readers. Moreover, papers accessible only behind a subscription paywall may be about connectivism, but since they are not participating in the broader open discussion of connectivism, they are hence are not a part of the development of connectivism.

While the results of such a survey are representative to a certain degree, they should be thought of more as a "snapshot" of the current discussion of connectivism taking place within connectivism rather than an empirical review of the state of the entire literature. Nor are all results ideal; of the 44 works studied, the sample included five incomplete excerpts from Google books, two detailed abstracts, and two results which were related to, but did not specifically mention, connectivism.

Content was organized into themes found in the selection of papers, and emphasis was placed as much on the range of ideas discussed as on the frequency of any given idea. This paper therefore should be best thought of as an interpretation of the literature, rather than as a quantified analysis of the literature.

\section{Overview of the Findings}

As mentioned above, a total of 44 papers were reviewed for the purposes of this study. They form a diverse collection of reviews, surveys and arguments drawn from researchers from around the world.

Five major types of paper predominate: conceptual papers considering the viability and applicability of connectivism as a theory; mixed-method surveys of teachers and learners; design papers applying connectivist principles to create learning opportunities; and papers that evaluate of learning outcomes in cases where connectivist principles are employed; and literature reviews focusing on some aspect of connectivism.

When we consider the attitudes toward connectivism expressed in these papers, it is worth noting that arguments against connectivism were found almost exclusively in the conceptual papers. Of the other papers, the predominant focus was on how and where to apply connectivism, or to 
employ connectivism to explain the design or the outcome of a learning opportunity. In those cases where connectivism was explicitly evaluated (either on its own or in comparison with another theory) in no case did the evidence mitigate against connectivism. Most outcomes were positive or at worst neutral.

Though a number of the papers addressed the employment of connectivism in language learning, no application or domain predominated. The theory was employed both online and in the classroom, in elementary education through college and to professional development. In addition to language learning authors examined its applicability in science and engineering, mathematics, health case, and even the design of cities.

A table of these findings is available in Appendix A.

In addition to these overall trends (a connectivist would say) it is equally important to look at patterns and theme that offer a perspective on the literature. This is an interpretive exercise and is focused on what can be seen in the papers rather than what can be counted. To that end, three two-part themes were identified:

- Overview and criticisms of connectivism;

- Interpretations of connectivism as a pedagogy and as a theory;

- Evidence for the success of and future roles for connectivism.

These themes form the basis for the content below, which is then followed with some brief overview remarks. Overall, 44 papers from the last year are cited for this paper, representing a robust and continued conversation with participants from around the world.

\section{How Connectivism is Being Interpreted}

\section{Knowledge}

As mentioned above, connectivism is sometimes depicted as a theory of knowledge.

This basis in a theory of knowledge continues into the more recent work being studied here. Díaz and Hernández de Frutos (2018), quoting Marrero-Guillamón (2012), write that knowledge is the set of connections in a network, and therefore, that learning is the ability to create and traverse those connections. Knowledge, they assert, "Connectivism refers to the knowledge that emerges in the network from the interaction within a group".

Knowledge, on this model, isn't something that can be programmed. "This process should not be perceived as a deterministic development" they write. "It may arise spontaneously, but it is something that should be encouraged". Cabrero and Román (2018) write that in connectivism

"knowledge is something unpredictable, unstable, uncontrollable and in continuous growth, which means that it goes beyond the total control of a person and might be in their external networks (communities, digital devices, etc.) constantly changing."

Knowledge is also recognized as something that is emergent, something that results from interactivity rather than being the contents of it, as described for example by Kim et al. (2019) as being "the presence of 'Gestalt phenomena', that is, that the whole is something other than the sum of its parts." In a similar vein, Wang (2018), for example, mentions "Distributed cognitive theory" in passing applies it to deep interaction and group meaning construction".

Overall, however, the idea of connectivism as a theory of knowledge is something that lies more in the background of these discussions. Beyond these examples, it is not discussed at any length. 


\section{Learning}

Connectivism is also seen in recent work (as it has from its original formulation) as informing and describing the learning process. Learning online is in some important ways fundamentally different from traditional learning. "The mental burdens of activity can be understood as dispersed physically, socially, and symbolically between individuals and the tools they are using." (Dieterle \& Clarke, 2008). Some authors focus on the role of connectivism in explaining how learning takes place in these networked environments. For example, Cabrero and Román (2018) suggest that connectivism describes how people adapt to changing environments by making new connections and identifying patterns.

In addition to offering an explanation of learning in these networks, connectivism offers a methodology for such learning, and this methodology is noted by several authors. Kultawanicha, Koraneekija, and Na-Songkhlaa (2015) observe that "the model of connectivism learning consists of 4 steps including: (1) Aggregating, (2) Remixing, (3) Repurposing, and (4) Feed Forward".

This is a model of network formation rather a model of knowledge acquisition. Students need to experience the continuous need to make new connections, whether to resources or to people.

"Decision-making is itself a learning process. Choosing what to learn and the meaning of incoming information is seen through the lens of a shifting reality. While there is a right answer now, it may be wrong tomorrow due to alterations in the information climate affecting the decision." (Mlasi \& Naidoo, 2018)

Thus, connectivism is concerned about far more than the cognitive aspect of learning.

"The connectivistic view includes elements like emotions, recent experiences, beliefs, and the surrounding environment (and) online social networks which are adaptive, fluid, and readily scalable in size and scope." (Johansson et al., 2018)

\section{Community}

Connectivism is understood as informing learning not only in humans but also in communities, as Cabrero and Román (2018) write,

"not only the idea of individual buman knowledge and learning, but also an approach to understand the collective mentality of a network of individuals, a community or a society based on the same principle: the generation of network ecologies constantly changing and evolving."

Consequently, connectivism is seen as proposing a methodology for making schools "smart". For example, Attar (2018) proposes the establishment of a knowledge and experience-sharing network between schools, teachers and students. Attar writes,

"To be able to perform in the new world of knowledge, we need to see the connecting forces. Connectivism and connective knowledge, meaning-making, pattern recognition and absolute certainty are our required skills."

Connectivism also offers principles for the organization of groups, suggesting (with Piao \& Ma, 2018) that "the combination and allocation of group members should comply with the principle of voluntariness," with members of the group each taking on an equal role and performing that role independently. 


\title{
Criticisms of Connectivism
}

\section{Student Agency}

In the early days of connectivism researchers raised the question of whether students would be able to manage to be self-directed and self-motivated learners. Kop (2011), for instance, after studying Personal Learning Environments, Networks and Knowledge (PLENK) 2010, an early connectivist course, concluded that not all students were able to autonomously direct their own learning and master critical literacies.

Additionally, some researchers found that students were disconnected from their online learning experience. Mackness and Bell (2015), cited by Gonçalves and Osório (2018), report that

$$
\begin{aligned}
& \text { "Although many students experienced the light side of the course, some had mixed feelings } \\
& \text { and experiences, while some even felt disconnected, demotivated, demoralized, disenfranchised, } \\
& \text { and disturbed - the dark side." }
\end{aligned}
$$

A similar criticism was offered in an extended argument by Pando:

\begin{abstract}
"Connectivism as a teaching trend of virtual education threatens in a way the buman condition with respect to their existential problems, their social ties, their values, due to the socalled, according to Bauman (2004), the generation of liquid modernity. So a new question arises: Has connectivism turned out to be a new behaviorism? Is it useful for the improvement of teaching-learning processes?" (Pando, 2018)
\end{abstract}

It could be argued that these concerns were not widespread, and that perhaps as students become more accustomed to working in social networks and digital technologies initial concerns about their capacity to flourish in such environments become less warranted.

\section{Conceptual Gaps}

Another line of criticism centres on the question of whether connectivism can explain conceptformation. Additionally, critics ask whether students employing connectivist methodology can independently create or construct conceptual knowledge.

This sort of argument is offered by Clarà and Barberà (2013b) citing the "learning paradox". This paradox, they write, "can be applied to connectivism as follows: How do you recognize a pattern if you do not already know that a specific configuration of connections is a pattern?" They also suggest that "connectivism underconceptualizes interaction and dialogue, by understanding it as a learner's connection to a human node in the network". Additional, they argue, "connectivism is unable to explain concept development".

Criticisms of this sort have persisted in recent years. For example, Al Dahdouh (2018) argues that connectivism cannot show how learners form connections to the variety of resources. A process over and above connectivist pedagogy seems to be required: "How a learner forms connection to a node can be summarized into three consecutive stages: (1) planning and forethought; (2) cognitive processing; (3) evaluating”.

Additionally, in a related but distinct strand of argumentation, Gonçalves and Osório argue, "there are no activities in MOOC that can be implemented collectively, so there is a tendency for the lack of involvement and participation of teachers". 


\section{Responses?}

In a 2019 blog post George Siemens appeared to recant on network learning based on objections similar to those outlined above (Siemens, 2019). He wrote,

"While networks have tremendous descriptive power, I've started to realize that they are insufficient. They can be predictive...but not at the level that I gleefully felt at one time.... all connections and networks occur within a system. The system sets the rules for connection forming and for action capabilities available to individuals."

Certainly there is no reason to believe that every network everywhere will enable individual agency and will be cognitively complete, that is, able to account for intellectual accomplishments such as the appreciation of universal principles or the comprehension of language, what Chomsky (1986) called "Plato's problem".

But there is more and more reason to believe that some networks can support agency and cognition. On receiving the 2019 Turing Award for his work in neural networks and connectionism, Geoffrey Hinton commented, "for a long time, neural networks were regarded as flaky in computer science...". But today they recognize handwriting, translate text, and even express creativity (Chung, 2019).

And in much of the recent discussion of connectivism there was less emphasis on the criticisms of connectivism than there was discussion about how connectivism should be understood, the conditions under which it should be applied, and how it can be successful. Let us turn to these discussions.

\section{Connectivism as Pedagogy}

\section{MOOCs}

The primary expression of connectivism as pedagogy over the last decade has been the MOOC; indeed, the first MOOC was titled "Connectivism and Connective Knowledge". Thus researchers continue to investigate the connection. For example, Mahmod, Ali, and Shah (2018) investigate "the global role of MOOCs in e-learning (which) has emerged due to learning theories related to learners whether individuals or networks of learners". Fondo and Konstantinidis (2018) employ connectivism in MOOC design that "occurs in complex (environments) and lacking definite form".

Zaduski, Lopes, and Schlunzen (2018) suggest that

"The principles are the same as those of OERs, that is, the contents organized and structured at the beginning of the course served more to initiate discussions and to foster curiosity rather than to be considered 'absolute trutbs' or as contents to be memorized and reproduced in assessments."

But would students learning in a MOOC exhibit connectivist learning? Studies suggest they do. For example,

"The interaction around topics and topic generation supports the idea of learning as network. creation after the analysis of participation patterns that are based on some deep interactive topic." (Wang, Anderson, \& Chen, 2018) 


\section{Classrooms}

Though connectivism was envisioned as a theory describing digital learning, numerous researchers applied connectivist pedagogical principles to classroom environments.

- Profit (2019) examined connectivism as being utilized is in Active Learning Classrooms (ALC) but suggested that the theory would need to be modified; citing Gebre et al. (2015) Profit argues that for an ALC to be effective, "three parts must be in place: the transmission of knowledge, engagement of students and the ability to develop learning independence."

- Similarly, Rice (2018) includes connectivism as only part of a broader approach to classroom learning, offering five strategies for implementing connectivism in the classroom. These strategies include "never providing information that students can access themselves," which pushes connectivism toward the model of discovery learning rather than network learning.

- Montebello (2018) employs connectivism in the context of classroom interaction. Connectivism "justifies how learners employ networked resources, as potentially those within an AmI classroom, to form connections and links to learn and share knowledge and ideas."

\section{Microlearning}

In corporate learning the concept of microlearning has achieved wide currency in recent years (Emerson \& Berge, 2018). Microlearning is learning that takes place in short intervals of time, with small units of content (Hug \& Friesen, 2017; p.17), and reflects "the emerging reality of the ever-increasing fragmentation of both information sources and information units used for learning”.

De Gagne et al. (2018) argue that "The theoretical basis of microlearning is connectivism", because connectivism is focused on the development of the ability to form links between many ideas, each with each other and with different source of information. "These connections between ideas in individual learners' brains are formed, developed and maintained in what Siemens calls learning ecologies", they write. "Learning ecologies can vary in size, scope and complexity, but they are all composed of networks of individuals and information Sources".

\section{Autonomy, Interactivity...}

As described by Al Dahdouh, Osórioand, and Caires (2015) and elsewhere, connectivism describes the principles for successful networks as autonomy, diversity, interactivity and openness. The discussion of connectivism as pedagogy sees researchers edging toward these principles.

Many of the writers described student autonomy as an essential principle in connectivist models of learning, depicting " $21^{\text {st }}$ century students as 'do-it-yourself learners" (Hazeldine, Yardley, \& Shearman, 2018). In MOOCs, in classrooms, in corporate microlearning, we see a greater emphasis on enabling the learner to choose what they learn and how they learn.

Interactivity has meanwhile been increasingly viewed not only as an effective pedagogical strategy but also as a means of creating and growing new learning. Researchers depict connectivism not merely as a means of knowledge transmission but as a means of solving problems and accomplishing tasks. For example, Madhok, Frank, and Heller (2018) write, 
"Our model of Global Learning is an extension of Connectivism to offer an innovative and practical approach to the enormous problem of global Public Health human resource shortages."

\section{Connectivism as a Theory of Learning}

\section{Arguments in Support}

Connectivism has often been positioned as a theory of learning alongside (for example) behaviourism, cognitivism and constructivism. Some authors take up this positioning explicitly.

What does it mean to be a theory of learning? Duke, Harper, and Johnston (2013) reflect the generally held beliefs that "a theory generally applies to the synthesis of a large body of information" and that something qualifies as a theory based on "whether it is useful or not useful for explaining or predicting behavior".

They contrast this with an instructional theory, which, they write, "must prescribe procedures to enable learning efficiently and effectively". Citing Bruner (1966) they argue that this includes such things as learning predisposition, concept design, the progression of ideas, and the employment of rewards and punishments.

\section{Objections}

From the outset various authors have argued that connectivism should not be considered a new theory of learning (Kerr, 2006; Kop \& Hill, 2008; Kop, 2011; Bell, 2011; Clarà \& Barberà, 2013a; Anderson \& Dron, 2011; 2012). These arguments have continued into some of the recent work in connectivism.

One current strand of argumentation is that connectivism should be seen as an extension of existing theories. (Homanova et al., 2018) For example, it is argued that it is "only the evolution of previous schools and not a theoretical revolution in pedagogy" (Cabrero \& Román, 2018). Or it extends the limits of constructivism (Mattar, 2018).

An additional strand of argumentation draws on criticisms of connectivism to suggest that it is not sufficiently robust to be considered a theory of learning. Clarà and Barberà (2013a), for example, argue that connectivism is unable to explain concept development. "If a concept consists of a specific pattern of associations, how can it be explained that the concept develops but the pattern of associations remains the same?"

Related to this is the idea that connectivism is not in itself sufficiently complete to be considered a theory of learning. Zheng et al. (2018) suggest that connectivism "does not explain how the information provided in the nodes is integrated into the existing knowledge structure of the network after the learning is built".

To understand the learning process, external factors may come into play. For example, Ament and Edwards (2018) point to the role of teachers and peer learning in a collective sense, while Al Dahdouh (2017) asks about the design and management of learning networks. He asks, "What does the person who is playing with the hyper-parameters represent in the human mind?" 


\section{Basis for Connectivism in Research}

Proponents of connectivism have responded that while connectivism is based in previous work, this does not mean that connectivism is identical to, or a part of, the theories produced by that work. Rather, connectivism is argued to be based on a set of ideas that brings together numerous strands of investigation.

For one, they draw a connection between connectivist MOOCs and the neurocognitive perspective. Connectivism itself is rooted in the study of artificial neural networks, a discipline known as connectionism. Al Dahdouh (2017) additionally draws comparisons between connectivism and the artificial neural network program.

Additionally, write Cabrero and Román (2018), connectivism reflects Gestalt principles such as similarity, proximity, and continuation explaining how human mind draws connections and associations. Kim et al. (2019) also present results linking Gestalt to connectionism. But of course connectivism, while explaining aspects of Gestalt theory, is nonetheless not the same as Gestalt theory.

A number of researchers argue that connectivism consonant with aspects of the constructivist research program.

"Connectivism agrees with Constructivism in a big part of this global view of the learner, as Connectivism also considers that the learner has a main role in the learning process." (Cabrero \& Román, 2018)

Similarly, some researchers cite Conversation Theory (Pask, 1975; Laurillard, 1993; 2002) and Actor-Network Theory (ANT) (Latour, 1987; Law, 1999) and Network Learning (Harasim, 1995) all as precedents, suggesting that connectivism is not sufficiently distinct from any of these to be treated as a learning theory in its own right.

It is not evident what the standard is for the distinctness necessary for something to be considered a theory in its own right. Clearly connectivism cannot be the same theory, or even an extension, of all of these theories. It is equally unlikely, given its connections to so many different theories, that it is the same as any one of them.

\section{Evidence for Success}

When connectivism was introduced, proponents argued that the objective of connectivism is not to support traditional content-knowledge models of learning outcomes, but rather to develop the capacity to learn and grow in a fluid network-based environment. How then are connectivist being assessed today?

\section{Motivation}

A number of studies point to an association between connectivism and increased motivation on the part of students to pursue their work more deeply and more independently, citing positive motivational outcomes such as academic self-efficacy and task value in learners (Kultawanicha, Koraneekija, \& Na-Songkhlaa, 2015; Prince, 2017, all as cited by Borna \& Fouladchang, 2018a).

Borna and Fouladchang (2018a), for example, write, "the experimental group which was trained using connectivism approach showed the more scores in the post-test of academic self-efficacy and task value compared to CLT approach... the use of connectivism theory in education and learning process will lead to increased motivational beliefs". In part, motivation was related to the use of modern technology. For example, in a survey of learning professionals, "most of the 
experts strongly agreed with using cloud-based tools and Connectivism learning method..." (Kultawanicha, Koraneekija, \& Na-Songkhlaa, 2015).

But most of all, motivation stems from autonomy, that is, the ability to manage one's own course of studies. "It's not social influence", write Fianu et al. (2018). It is traceable to the pedagogy and the learning environment. As Angelini and Gasbarri (2018) write:

\section{"Autonomy and scaffolding represent the main components in promoting intrinsic motivation in learning pharmaceutical sciences, beside competence and relatedness. The high scores associated with student performances reflect our efforts to improve their self-confidence with organic chemistry, confirming the importance of motivational approaches."}

\section{Improved Outcomes based on Method}

Instructional methods associated with connectivism were reported as improving learning outcomes. (Sarnok \& Wannapiroon, 2018; Vas, Weber, \& Gkoumas, 2018; Cao, 2018). The selection of relevant and context-sensitive resources was related to a reduced number of errors and improved learning.

In one case, "the study revealed that autonomy, diversity, interactivity, openness and Web 2.0 have a positive significant effect on students' achievement" (Zulkifley, Nor, \& Siti, 2018).

In another, it was shown that "the connectivism instructional method was significantly more effective than grammar-translation method" (Borna \& Fouladchang, 2018b). Students "have opportunities to increase academic engagement through diversity and attention to the individual's interest in choosing content or tasks."

\section{Ability to Learn}

Connectivism has also been associated with an increased ability to learn on the part of students. This stems partially from their increased capacity to self-manage and partially from the more reliable world-view offered by a connectivist perspective.

For example, with respect to self-management "Students in higher education learning environments will prepare for the future when they become self-directed learners and more motivated by learning than performance," write Sarnok and Wannapiroon (2018).

And with respect to the connectivist perspective, students "learnt that people generally see the world not as it is, but as they are, or, as they are conditioned to see it" (Shrivastava, 2018). Thus we see a connection being drawn between the connectivist conception of knowledge and improved learning outcomes.

\section{Moving Forward}

\section{Role of Connectivism}

By and large, authors are in broad agreement that connectivism has a role to play in the future of learning and development.

There is a need for connectivist models.

"It is important to reflect on concepts such as open education, open educational resources, connectivism and rbizomatic learning environments, given that these are themes that are articulated and strengthened due to the cyberculture." (Zaduski, Lopes, \& Schlunzen, 2018) 
Additionally, some aspects of connectivism are needed to be successful in digital environments. For example,

$$
\begin{aligned}
& \text { "giving students a sense of control also seems to be vital in successful SNS use. In this case, it } \\
& \text { was done through students' control over the content and direction of the debate and how and } \\
& \text { when they engaged in online negotiation." (Pallas, Eidenfalk, \& Engel, 2018) }
\end{aligned}
$$

These are all aspects of what Bolstad et al. (2012) refer to as "emerging principles for a $21^{\text {st }}$ century education system". They point to the need for personalizing learning, diversity and inclusivity, developing a learning capacity, and a culture of continuous learning (pp.3-5). Connectivism places these themes into a single framework and provides a basis for understanding why these needs have emerged.

Connectivism also fosters critical thinking and deep learning, which educators see as essential moving forward.

$$
\begin{aligned}
& \text { "The author believes that critical thinking is a means to achieve deep learning, the cultivation } \\
& \text { of critical thinking ability and other higher-order thinking ability is the goal of deep learning, } \\
& \text { while deep learning research is the focus of learning science research." (Wang, 2018) }
\end{aligned}
$$

And connectivism can be seen as a response to constructivism, which backgrounds the role of the instructor.

\section{"Based on the theory of connectivism, educators take an essential role in digital learning." (Wei \& Hu, 2018)}

\section{Thinking of Connectivism More Widely}

Connectivism isn't simply a theory that describes and explains how to teach a certain body of knowledge to students. Its success isn't measured in summative evaluations of pre-established learning objectives. Rather, it focuses on a wider understanding of learning and fosters a broadbased capacity to learn and adapt in dynamic and chaotic environments (Bowes \& Swanwick, 2018).

Writers are demonstrating an increasing awareness of connectivism's wider role. For example, as Cabrero and Román (2018) write, "Connectivism foresees a better understanding of a society in constant change and a knowledge continuously growing". And Jirasatjanukul and Jeerungsuwan (2018) apply connectivism "the stage involved the setting of the learning aims".

As a result, research has focused on connectivist methods and practices in general. Some writers (Tucker, Wycoff, \& Green, 2017) look at teaching practices: "personalization, agency, authentic audience, connectivist, creativity". Others (Hazeldine, Yardley, \& Shearman, 2018) look at the role of the student in learning: "A combination of flexibility in learning with supported learner autonomy leads to both the development of learners' understanding and confidence".

Additionally, writers have examined what connectivism has to say about the learning environment in general, for example, describing "a robust, heterogeneous personal learning network that allows me to collaborate with people around the globe" (Ankel \& Swaminathan, 2018).

From the Open Source Educative Processes framework (OSEP; Glassman et al., 2011; Glassman \& Kang, 2016) to the concept of Cognitive Cities (Tabacchi et al., 2018) writers and educators are looking more deeply at the idea that "online communities have become a driving force in knowledge production and dissemination" (Kuznetcova, Glassman, \& Lin, 2018). 
And they underline the role of these networks not merely in the transmission of knowledge, but in the creation of it. This is recognized explicitly by the concept of the Virtual Communities of Building Knowledge (VCBK) (Díaz \& de Frutos, 2018).

"GNU/Linux is a program developed by a VCBK... learning and knowledge are not transferred from one network. member to another, but rather the product of the creative acts of all members' interactions. That was the key moment when the course $6.002 x$ becomes a $V C B K$. Perhaps the most important aspect of a MOOC is that learning and knowledge are the result of group interaction by means of technology..." (Diaz \& de Frutos, 2018)

\section{Concluding Remarks}

When connectivism was introduced its proponents described it not only as a learning theory for the digital age but also as a new approach to knowledge and learning as a whole. Connectivist principles, they argued, could be found in a variety of disciplines, these ranging from graph theory to connectionism to neural network theory to social networks.

In the fifteen years since our knowledge of all of these disciplines has grown. None of them has been without its issues, from the fears related to neural-network-inspired artificial intelligence to the abuses of social networks to the transformation of graph theory into applications such as blockchain and GitHub. And connectivism, too, has grown and become more widely understood during that time.

What can be said of connectivism based on current work in the field? Though that depends to a large degree what one expects from a learning theory, some more general remarks can be made. Consider different ways a theory can be evaluated. One might ask whether the theory is conceptually coherent. It might be asked whether the theory is useful and can be applied in practice. Additionally, one may ask whether a theory actually explains the phenomena it encompasses. And finally, one may ask whether the theory is predictive, and in particular, whether its application can produce desirable outcomes.

With respect to coherence, the greatest challenges are posed at the conceptual level, where it is held, variously, that either connectivism is not a theory, only an extension of previous theories, or represents the more negative aspects of a digital learning environment. It may be that all of these are true, though we can find arguments against each of them. But even if true, none of these show that connectivism is incoherent. Whether or not desirable, it does remain evident, through the ongoing application of connectivism to diverse cases, that connectivism says something valuable.

And in fact, that value shows in its application. The primary evidence that something is useful, it is said, is that it is used. There is evidence aplenty in the literature that it is used. Certain principles of connectivism (and especially the core principles of autonomy, diversity, openness and interactivity) can be observed in multiple cases where learning is being planned, designed, implemented and evaluated. It is being used in multiple disciplines, and at various levels of instruction, around the world.

In addition to being used to design and develop learning opportunities, as seen in a number of connectivism, as a theory, offers proponents an explanation for the results being observed. These explanations appealed to specific phenomena - the utility of social networks, increased student motivation, the development of deep learning - and traced them back to features of connectivism, such as interaction, autonomy, or network effects. 
And these speak, ultimately, to the outcomes observed and evidence for success identified in different studies. It should be noted that what counts as success varies from case to case; it's not merely retention and test scores. While connectivism appears to be effective in learning in complex domains, such as language learning, it also appears to produce positive outcomes beyond the individual course context. People who learn in a connectivist context not only learn, they can be seen to learn how to learn, and how to produce new knowledge.

To be sure, this survey does not reveal a unanimity of voices around a single statement or set of principles (this would in any case be unlikely given the nature of connectivism). But it does signify a broad awareness and acceptance of the role of networks in learning, and significantly, the positive impact of network principles such as autonomy and interactivity. Critics of connectivism may remain, but on the whole, it appears that connectivism, in 2019, is being broadly and usefully applied.

\section{References}

1. Al Dahdouh, A. A. (2017). Does Artificial Neural Network support Connectivism's assumptions? International Journal of Instructional Technology and Distance Learning, 14(3).

2. Al Dahdouh, A. A. (2018). Jumping from one resource to another: how do students navigate learning networks? International Journal of Educational Technology in Higher Education, 15(45). Retrieved from https://link.springer.com/article/10.1186/s41239-018-0126-x

3. Ament, V., \& Edwards, R. (2018). Better Teaching and More Learning in Mobile Learning Courses: Towards a Model of Personable Learning. In I. A. Sánchez, \& P. Isaias (Eds.), Proceedings of the 14 $14^{\text {th }}$ International Conference on Mobile Learning (pp. 214-220). IADIS Press, 2018.

4. Anderson, T., \& Dron, J. (2011). Three generations of distance education pedagogy. The International Review of Research in Open and Distributed Learning, 12(3), 80-97. Retrieved from http://www.irrodl.org/index.php/irrodl/article/view/890

5. Anderson, T., \& Dron, J. (2012). Learning technology through three generations of technology enhanced distance education pedagogy. European Journal of Open, Distance and elearning, 15(2). Retrieved from

http://www.eurodl.org/index.php?p $=$ archives\&year $=2012$ \&halfyear $=2 \&$ article $=523$

6. Angelini, G., \& Gasbarri, C. (2018). Learning organic chemistry day by day: The best choice of the best pharmacy students. Currents in Pharmacy Teaching and Learning, 10(6), 795-802. https://doi.org/10.1016/j.cptl.2018.03.003

7. Ankel, F., \& Swaminathan, A. (2018). Creating a robust personal learning network by nurturing weak ties. In F. Ankel, \& A. Swaminathan (Eds.), Adaptive Leadership for the New \#MedEd: The One Hour Read. Royal College of Physicians and Surgeons of Canada, Retrieved from http://www.royalcollege.ca/rcsite/documents/canmeds/adaptive-leadership-ebooke.pdf\#page $=24$

8. Attar, M. (2018). Connectivism theory a noteworthy necessity in the process of making schools smart. Proceedings: International Conference on Psychology, Educational and Behavioral Sciences. Volume 3. Retrieved from https://www.sid.ir/en/seminar/ViewPaper.aspx?FID=612E20180301

9. Bell, F. (2011). Connectivism: Its place in theory-informed research and innovation in technology-enabled learning. The International Review of Research in Open and Distributed Learning, 12(3), 98-118. Retrieved from http://www.irrodl.org/index.php/irrodl/article/view/902/1664 
10. Bolstad, R., Gilbert, J., McDowall, S., Bull, A., Boyd, S., \& Hipkins, R. (2012). Supporting future-oriented learning \& teaching - a New Zealand perspective Report to the Ministry of Education. New Zealand Council for Educational Research. Retrieved from https://nicspaull.files.wordpress.com/2017/03/bolstad-et-al-2012-nz-future-oriented07062012.pdf

11. Borna, M., \& Fouladchang, M. (2018a). The Motivational Outcomes of Connectivism Theory in EFL. Modern Journal of Language Teaching Methods, 8(2), 101-112. Retrieved from http://mjltm.org/article-1-278-en.html

12. Borna, M., \& Fouladchang, M. (2018b). The Comparison Of effectiveness Connectivism Instructional Method with Grammar-Translation Method on Students' Academic Engagement in EFL. Modern Journal of Language Teaching Methods, 8(4), 88-98. Retrieved from http:/ / mjltm.org/article-1-77-en.pdf\#page $=88$

13. Bowes, M., \& Swanwick, C. (2018). Using connectivism to theorise developments in digital technology in physical education in Aotearoa/New Zealand. In J. Koekoek, \& I. van Hilvoorde (Eds.), Digital Technology in Physical Education: Global Perspectives (pp. 204-222). Routledge.

14. Bruner, J. (1966). Toward a theory of instruction. Cambridge, MA: Harvard University Press.

15. Cabrero, R. S., \& Román, O. C. (2018). Psychopedagogical Predecessors of Connectivism as a New Paradigm of Learning. International Journal of Educational Excellence, 4(2), 29-45.

16. Cao, L. (2018). Study on College English Teaching Interaction and Teaching Practice Based on Connectivism from the Neurocognitive Perspective. Educational Sciences: Theory \& Practice, 18(5), 2338-2346. http://dx.doi.org/10.12738/estp.2018.5.132

17. Chomsky, N. (1986). Knowledge of Language. Praeger.

18. Chung, E. (2019 March 27). Canadian researchers who taught AI to learn like humans win $\$ 1 \mathrm{M}$ Turing Award. CBC News [blog post]. Retrieved from https://www.cbc.ca/news/technology/turing-award-ai-deep-learning-1.5070415

19. Clarà, M., \& Barberà, E. (2013a). Three problems with the connectivist conception of learning. Journal of Computer Assisted Learning, 30(3), 197-206. doi: 10.1111/jcal.12040. Retrieved from https://onlinelibrary.wiley.com/doi/abs/10.1111/jcal.12040

20. Clará, M., \& Barberá, E. (2013b). Learning online: Massive open online courses (MOOCs), connectivism, and cultural psychology. Distance Education, 34(1). Retrieved from https://www.researchgate.net/publication/259812104_Learning_online_Massive_open_onli ne_courses_MOOCs_connectivism_and_cultural_psychology

21. De Gagne, J. C., Woodward, A., Park, H. K., Sun, H., Yamane, S. S. (2018). Microlearning in health professions education: a scoping review protocol. JBI Database of Systematic Reviens and Implementation Reports: June 2019, 17(6), 1018-1025.

https://journals.lww.com/jbisrir/Abstract/onlinefirst/Microlearning_in_health_professions _education__a.99966.aspx

22. Díaz, J. A., \& de Frutos, T. H. (2018). Connectivism in the Network Society. The Coming of Social Capital Knowledge. Tendencias Sociales. Revista de Sociologia, 1(2018), 21-37. Retrieved from http://revistas.uned.es/index.php/Tendencias/article/view/21358/17565

23. Dieterle, E., \& Clarke, J. (2008). Multi-User Virtual Environments for Teaching and Learning. In M. Pagani (Ed.), Encyclopedia of multimedia technology and networking (2 ${ }^{\text {nd }} \mathrm{ed} . \mathrm{pp}$. 1033-1041). Hershey, PA: Idea Group, Inc. Retrieved from https://www.researchgate.net/publication/250016409_MultiUser_Virtual_Environments_for_Teaching_and_Learning/download 
24. Duke, B., Harper, G., \& Johnston, M. (2013). Connectivism as a Digital Age Learning Theory. The International HETL Review, Special Issue, 2013, 4-13. Retrieved from https://www.hetl.org/wpcontent/uploads/2013/09/HETLReview2013SpecialIssueArticle1.pdf

25. Emerson, L. C., \& Berge, Z. L. (2018). Microlearning: Knowledge management applications and competency-based training in the workplace. Knowledge Management \& E-Learning, 10(2), 125-132. retrieved from http://www.kmel-journal.org/ojs/index.php/onlinepublication/article/view/17

26. Fianu, E., Blewett, C., Oppong, G., Ampong, A., \& Ofori, K. S. (2018). Factors Affecting MOOC Usage by Students in Selected Ghanaian Universities. Education Sciences, 8(2). Retrieved from https://www.mdpi.com/2227-7102/8/2/70

27. Fondo, M., \& Konstantinidis, A. (2018) Design of a MOOC on personal language learning environments for digital language skills development. In P. Taalas, J. Jalkanen, L. Bradley, \& S. Thouësny (Eds.), Future-proof CALL: language learning as exploration and encounters - short papers from EUROCALL 2018. Research-publishing.net, Dec. 8, 2018. Retrieved from https:/ / books.google.ca/books?hl=en\&lr $=\& \mathrm{id}=\mathrm{qRx}-$ DwAAQBAJ\&oi $=$ fnd $\& p g=$ PA64\&dq $=$ connectivism\&ots $=$ S1mJfMMB_\&sig=SalCr3Qk0WkN3Yrzg2GcyHjGyWA\#v $=$ onepage\&q=connectivism\&f $=$ fal se

28. Gonçalves, B. M. F., \& Osório, A. J. (2018). Massive Open Online Courses (MOOC) to improve teachers' professional development. RE@D - Revista de Educação a Distância e Elearning, 1(1), 52-63. Retrieved from https://journals.uab.pt/index.php/lead_read/article/view/146

29. Harasim, L. M. (1995). Learning networks: A field guide to teaching and learning online. MIT press.

30. Hazeldine, L., Yardley F., \& Shearman, J. (2018). Flexible autonomy: an online approach to developing mathematics subject knowledge for teachers. In J. Golding, N. Bretscher, C. Crisan, E. Geraniou, J. Hodgen, \& C. Morgan (Eds.), Research Proceedings of the $9^{\text {th }}$ British Congress on Mathematics Education (3-6 April 2018, University of Warwick, UK). Retrieved from http://www.bsrlm.org.uk/wp-content/uploads/2018/11/BCME9-Research-

Proceedings.pdf\#page $=65$

31. Homanova, Z., Prextova, T., \& Klubal, L. (2018). Connectivism in Elementary School Instruction. In K. Ntalianis, A. Andreatos, \& C. Sgouropoulou. (Eds.), ECEL $201817^{\text {th }}$ European Conference on e-Learning. Retrieved from https://books.google.ca/books?hl=en\&lr=\&id=Jox5DwAAQBAJ\&oi=fnd\&pg=PA177\&dq $=$ connectivism\&ots $=$ hb8bemxYX $4 \&$ sig $=0$ ssddSNjmzjQ8onHICroxYLOxM\# $_{\mathrm{v}}=$ onepage\&q\&f$=$ false

32. Hug, T., \& Friesen, N. (2007). Outline of a Microlearning Agenda. In T. Hug (Ed.), Didactics of Microlearning.

33. Jirasatjanukul, K., \& Jeerungsuwan, N. (2018). The Design of an Instructional Model Based on Connectivism and Constructivism to Create Innovation in Real World Experience. International Education Studies, 11(3), 12-17. Retrieved from http:// files.eric.ed.gov/fulltext/EJ1172128.pdf

34. Johansson, J., Contero, M., Company P., \& Elgh, F. (2018). Supporting connectivism in knowledge based engineering with graph theory, filtering techniques and model quality assurance. Advanced Engineering Informatics, 38, October 2018, 252-263. https://doi.org/10.1016/j.aei.2018.07.005 
35. Kerr, B. (2006. December 26). A Challenge to Connectivism. Transcript of Keynote Speech, Online Connectivism Conference. BILL KERR, wandering, wandering ... [blog post]. Retrieved from http://billkerr2.blogspot.com/2006/12/challenge-to-connectivism.html

36. Kim, B., Reif, E., Wattenberg, M., \& Bengio, S. (2019). Do Neural Networks Show Gestalt Phenomena? An Exploration of the Law of Closure. arXiv, Mar 15, 2019. https://arxiv.org/pdf/1903.01069.pdf

37. Kop, R. (2011). The challenges to connectivist learning on open online networks: Learning experiences during a massive open online course. The International Review of Research in Open and Distributed Learning, 12(3), 19-38. Retrieved from http://www.irrodl.org/index.php/irrodl/article/view/882

38. Kop, R., \& Hill, A. (2008). Connectivism: Learning theory of the future or vestige of the past? The International Review of Research in Open and Distance Learning, 9(3). Retrieved from http://www.irrodl.org/index.php/irrodl/article/view/523/1137

39. Kultawanich, K., Koraneekij, P., \& Na-Songkhl, J. (2015). A Proposed Model of Connectivism Learning Using Cloud-based Virtual Classroom to Enhance Information Literacy and Information Literacy Self-efficacy for Undergraduate Students. Social and Behavioral Sciences, 191, $87-92$.

40. Kuznetcova, I. Glassman, M., \& Lin, T-J. (2018). Multi-user virtual environments as a pathway to distributed social networks in the classroom. Computers \& Education, 130, November 2018. Retrieved from https://www.researchgate.net/publication/328994039

41. Latour, B. (1987). Science in Action: How to Follow Scientists and Engineers through Society. Open University Press.

42. Laurillard, D. (1993). Rethinking University Teaching: A Framework for the Effective Use of Educational Technology. Routledge.

43. Laurillard, D. (2002). Rethinking University Teaching. A conversational framework for the effective use of learning technologies. Routledge.

44. Law, J. (1999). After ANT: Complexity, Naming and Topology. In J. Hassard, \& J. Law (Eds.), The Sociological Review (Volume 47, Issue 1, pp. 1-14). Blackwell Publishers.

45. Mackness, J., \& Bell, F. (2015). Rhizo14: A rhizomatic learning cMOOC in sunlight and in shade. Open Praxis, 7(1), 25-38. Retrieved from https://openpraxis.org/index.php/OpenPraxis/article/view/173

46. Madhok, R., Frank, E., \& Heller, R. F. (2018). Building public health capacity through online global learning. Open Praxis, 10(1), 91-97. retrieved from https://www.learntechlib.org/p/182379/

47. Mahmod, M. A., Ali, A. B. Md., \& Shah, A. (2018). Massive Open Online Courses as an Augmentation of E-Learning: A Review. International Journal on Perceptive and Cognitive Computing, 4(2). Retrieved from http://journals.iium.edu.my/kict/index.php/IJPCC/article/download/69/51

48. Mattar, J. (2018). Constructivism and connectivism in education technology: Active, situated, authentic, experiential, and anchored learning. RIED: Revista Iberoamericana de Educación a Distancia, 21(2), 201-217. Retrieved from http://revistas.uned.es/index.php/ried/article/view/20055 
49. Mlasi, S. M., \& Naidoo, R. (2018). An Exploratory Study of the ODL Course in Structural Engineering. Proceedings of the $10^{\text {th }}$ International Conference on Computer Supported Education (CSEDU 2018) - Volume 2, 246-251. Retrieved from https://www.scitepress.org/papers/2018/67513/67513.pdf

50. Montebello, M. (2018). Contextual Dimensions of an Ambient Intelligent Classroom. In J. Kay, \& R. Luckin (Eds.), Rethinking Learning in the Digital Age: Making the Learning Sciences Count, $13^{\text {th }}$ International Conference of the Learning Sciences (ICLS) 2018, Volume 3. London, UK: International Society of the Learning Sciences. Retrieved from https://repository.isls.org//handle/1/629

51. Pallas, J., Eidenfalk, J., \& Engel, S. N. (2019). Social networking sites and learning in international relations: The impact of platforms. Australasian Journal of Educational Technology, 35(1), 16-27. Retrieved from https:/ / ro.uow.edu.au/cgi/viewcontent.cgi?article=4445\&context=lhapapers

52. Pando, V. F. (2018). Teaching Trends in Virtual Education: An Interpretative Approach. Propósitos y Representaciones, Ene.Jun. 2018, 6(1), 463-505. http://dx.doi.org/10.20511/pyr2018.v6n1.167

53. Pask, G. (1975). Conversation, cognition and learning. New York: Elsevier.

54. Piao, Y., \& Ma, J. (2018). Teaching Design Strategy of Innovation and Entrepreneurship Course of College Students. Proceedings of the $4^{\text {th }}$ International Conference on Arts, Design and Contemporary Education (ICADCE 2018). Retrieved from https://www.atlantispress.com/proceedings/icadce-18/25900351

55. Profit, J. E. (2019). Student Perception of Digital Technology Usage in Higher Education Classrooms at Seattle Pacific University. Education Dissertations. 37. Retrieved from https://digitalcommons.spu.edu/soe_etd/37

56. Rice, R. (2018). Implementing Connectivist Teaching Strategies in Traditional K-12 Classrooms. In F. H. Nah, \& B. Xiao (Eds.), HCI in Business, Government, and Organizations. HCIBGO 2018. Lecture Notes in Computer Science (vol. 10923, pp. 645-655). Springer. Retrieved from https://link.springer.com/chapter/10.1007/978-3-319-91716-0_51

57. Sarnok, K., \& Wannapiroon, P. (2018). Connectivism Learning Activity in Ubiquitous Learning Environment by Using IoE for Digital Native. Veridian E-Journal, Silpakorn University (Humanities, Social Sciences and arts), 11(4), 405-418. https://tci-thaijo.org/index.php/VeridianE-Journal/article/view/125566

58. Shrivastava, A. (2018). Using connectivism theory and technology for knowledge creation in cross-cultural communication. Research in Learning Technology, 26. https://doi.org/10.25304/rlt.v26.2061

59. Siemens, G. (2004). Connectivism: A theory for the digital age. Retrieved from http://www.elearnspace.org/Articles/connectivism.htm

60. Siemens, G. (2019). I was wrong about networks. LinkedIn, March 26, 2019. Retrieved from https://www.linkedin.com/pulse/i-wrong-networks-george-siemens/

61. Tabacchi, M. E., Portmann, E., Seising, R., \& Habenstein, A. (2018). Designing Cognitive Cities. In E. Portmann, M. E. Tabacchi, R. Seising, \& A. Habenstein (Eds.), Designing Cognitive Cities. Springer.

62. Tucker, C. R., Wycoff, T., \& Green, J. T. (2017). Blended Learning in Action: A Practical Guide toward Sustainable Change. Corwin Press. 
63. Vas, R., Weber, C., \& Gkoumas, D. (2018). Implementing connectivism by semantic technologies for self-directed learning. International Journal of Manpower, 39(8), 1032-1046. Retrieved from https://www.emeraldinsight.com/doi/abs/10.1108/IJM-10-2018-0330

64. Wang, H. (2018). A Study on Deep Learning and Its Enlightenment on China's Foreign Language Learning. Proceedings of the $2^{\text {nd }}$ International Conference on Education Science and Economic Management (ICESEM 2018). Advances in Social Science, Education and Humanities Research (ASSEHR), volume 184, 157-166. Retrieved from https://www.atlantispress.com/proceedings/icesem-18/25900935

65. Wang, Z., Anderson, T., \& Chen, L. (2018). How Learners Participate in Connectivist Learning: An Analysis of the Interaction Traces From a cMOOC. International Review of Research in Open and Distributed Learning, 19(1).

66. Wei, Y., \& Hu, J. (2018). A Cross-Sectional Evaluation of EFL Students' Critical Thinking Dispositions in Digital Learning. In T. Hauer, \& W. K. Mujani (Eds.), Proceedings of the 2018 International Seminar on Education Research and Social Science (ISERSS 2018) (pp. 27-30). https://dx.doi.org/10.2991/iserss-18.2018.8

67. Zaduski, J. C. D., Lopes, R. B., \& Jr., Schlünzen, K. (2018). Initial considerations about a rhizomatic learning environment. Revista Ibero-Americana de Estudos em Educação, 138(Extra 1), 489-499. Retrieved from https://dialnet.unirioja.es/servlet/articulo?codigo=6465744

68. Zheng, Q., Chen, L., \& Burgos, D. (2018). The Development of MOOCs in China. Springer Nature Singapore Pte Ltd. Retrieved from https://link.springer.com/chapter/10.1007/978981-10-6586-6_3

69. Zulkifley, M., Nor, U., \& Siti, Y. (2018). An Evaluation of Structural Model for Independent Learning Through Connectivism Theory and Web 2.0 towards Students' Achievement. Proceedings of the International Conference on Applied Science and Engineering (ICASE 2018). Atlantis Press. Retrieved from https://www.atlantis-press.com/proceedings/icase-18/25904518 


\section{Appendix A}

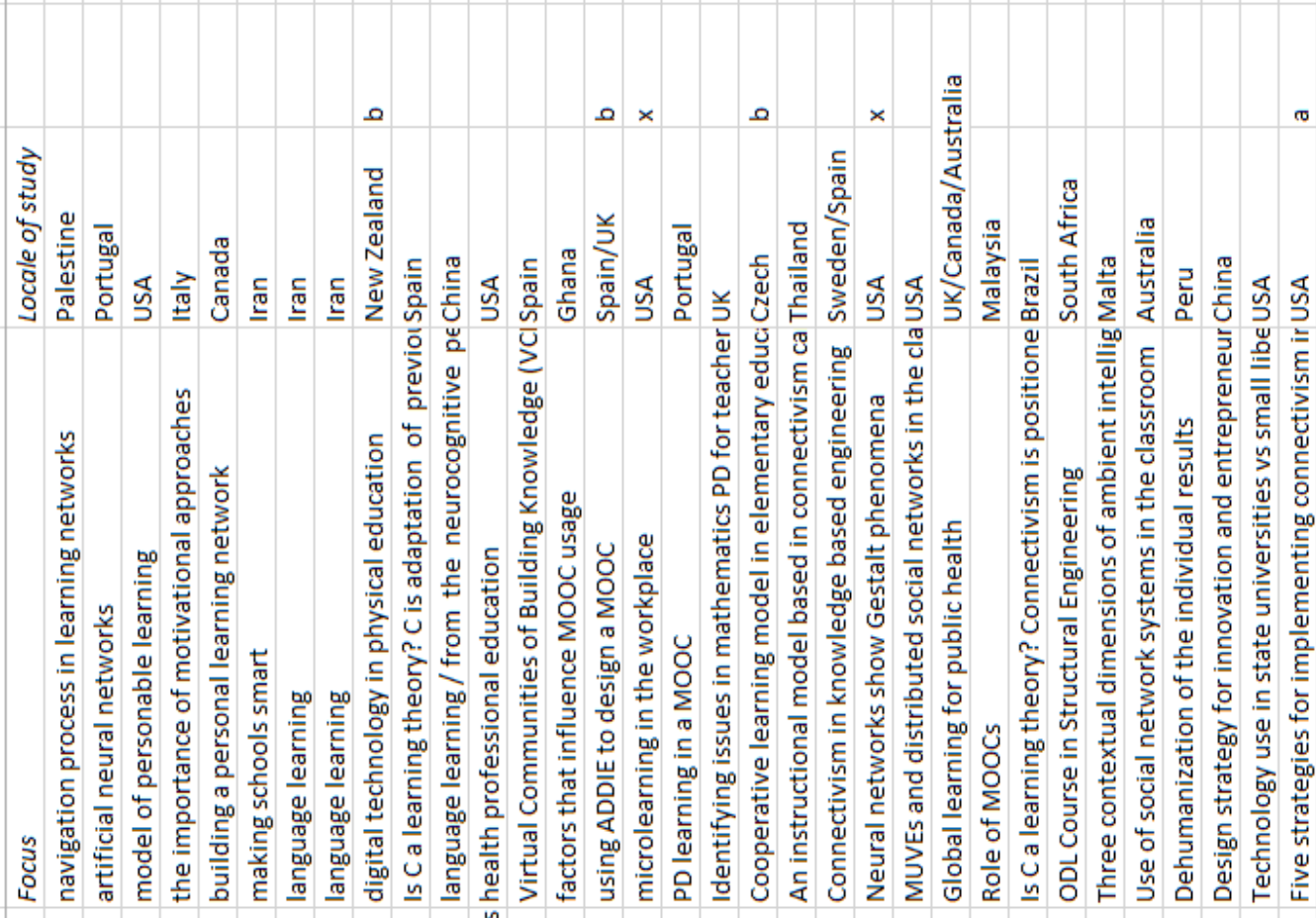

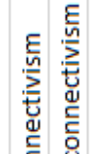

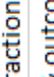

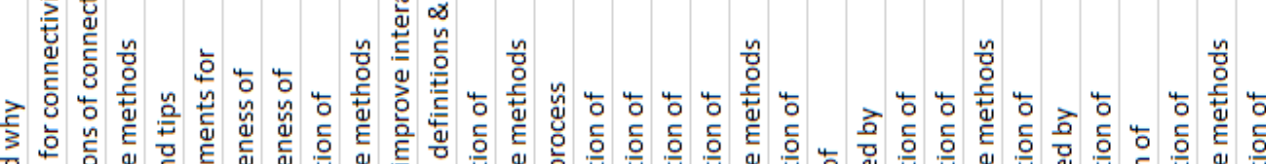

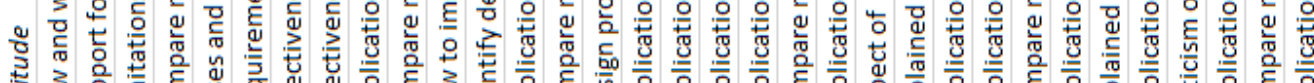

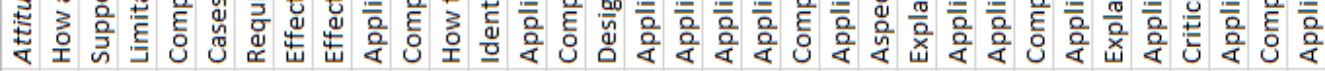

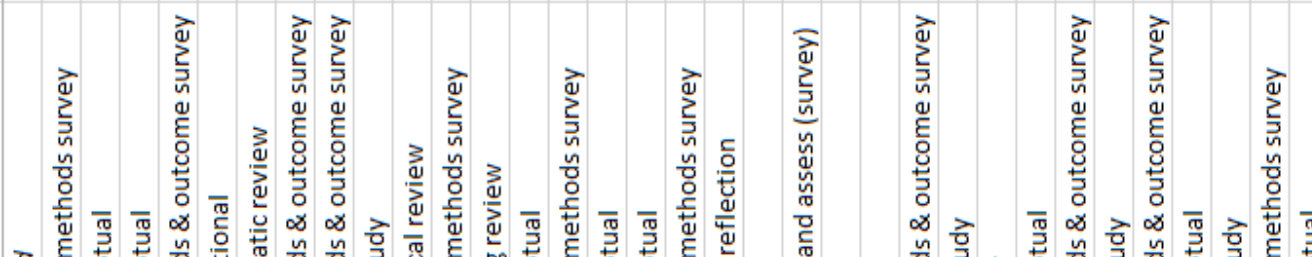

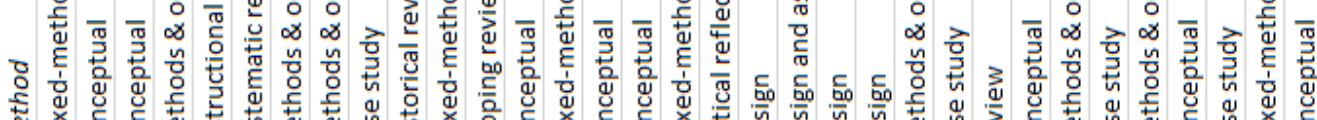

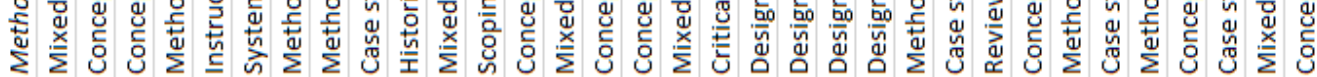

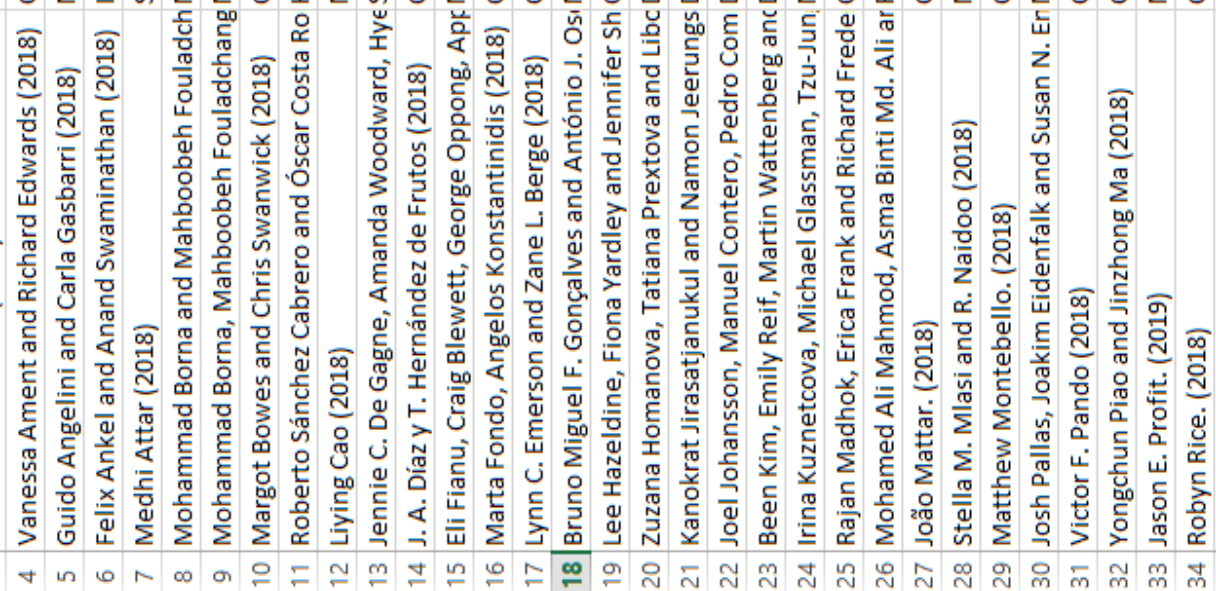




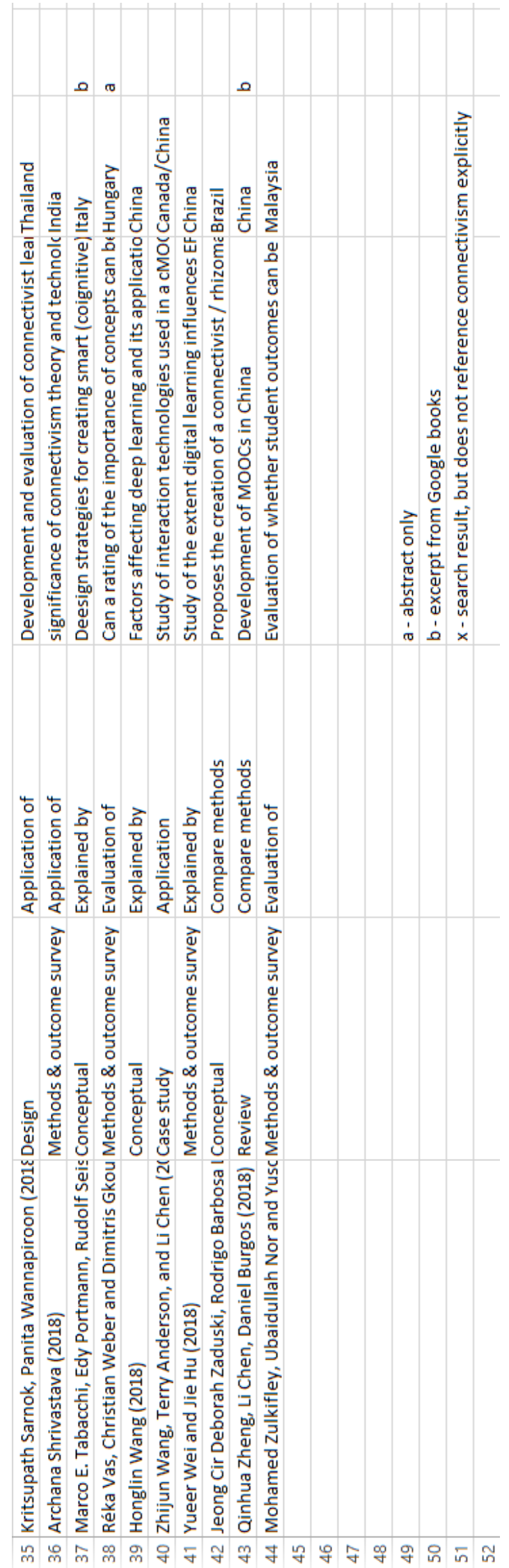

